\title{
RELIGION AND CHURCH IN CENTRAL AND EASTERN EUROPE
}

\section{Palinchak M. M.}

\section{INTRODUCTION}

World War II changed the course of history of Central and Eastern Europe. Traditionally, being a frontier or half-division of the West, the region has become a Western continuation of the Soviet Union. Czechoslovakia, Poland and Hungary were in a semi-colonial dependence on the USSR, which was far behind them in the cultural, social, economic and political terms [see ${ }^{1}$, p. 292-302].

Churches in Central and Eastern European countries, even in the Soviet period, were officially recognized as an important factor in the preservation of national identity, and emphasized on the fruitfulness of their efforts in the area of raising social morality and patriotic education.

The fact that the churches, contrary to everything, played a positive role in peaceful revolutions, accelerating the collapse of the communist regime, confirms that totalitarian regimes always fail in their attempts to abolish religion. Moreover, anti-religious propaganda and persecution of believers indirectly worked on the authority of churches, and their influence in society became more significant.

Analysis of recent research and publications. A significant contribution to the study of this topic was made by domestic and foreign scientists. To name a few Barnackevich Yu., Burakov Yu.V., Kiparenko G.M., Movchan S.P., Moroz Yu.M., Vandich P., Yelensky V., Konotop L.G., Kril M.M., Mariansky Ya., Ovsienko F. G., and others.

The purpose of this study is to analyze the state - church relations in the countries of Central and Eastern Europe.

Research results. Since 1948, communism in Central and Eastern Europe has acquired its extreme form - Stalinism, for which there is a strict homogeneity in the imitation of the Soviet model and subordination to Moscow. "Love for the Soviet Union does not suffer any reservations," wrote the Czechoslovak newspaper "Red Law" on May 25, 1952. [Cite: ${ }^{2}$, p. 306].

${ }^{1}$ Вандич П. Ціна свободи. Історія Центрально-Східної Європи від Середньовіччя до сьогодення / П. Вандич. - К.: Критика, 2004. - 463 с.

${ }^{2}$ Вандич П. Ціна свободи. Історія Центрально-Східної Європи від Середньовіччя до сьогодення / П. Вандич. - К.: Критика, 2004. - 463 с. 
Most modern researchers focus on the rule in the communist era in Central and Eastern European of totalitarian model of rigid and antagonistic separation of church and state $\left[{ }^{3}\right.$, p. 31]. This model, with a greater or lesser consistency, was realized by the USSR, whose amplitude of religious policy was more than tangible: from the bloody terror at one pole, which destroyed more than 50 thousand only Orthodox clergy, to the imperial policy of introducing the "main church of the main people" into the system of state propaganda; from quite serious attempts to "finally resolve the religious issue" to the so-called "religious nep" and to direct the priests to the "Soviet patriotism".

In its "middle values", this model, is typical of most countries of the former "socialist camp," boiled down to total control over religious activity, its almost total restriction on the cult sphere, repression against religious dissidents, priests and ordinary believers who prevented the nomenclature. This model was also aimed, on the one hand, at creating a strong infrastructure for eradicating "religious prejudice" and, on the other, for using the church hierarchy in foreign policy to promote the "peace" of the Warsaw Pact and the benefits of the "socialist way of life." Under these conditions, religious freedom in Central and Eastern European countries was, at these times, a dead law that remained only on paper on which the Constitutions were written [See details: ${ }^{4}$ ].

As for religion in Poland, it can be stated with certainty that the Church and the Polish state have a tendency to maintain tolerant relations, but this was not always the case. In general, more or less tolerant links existed before the implementation of communist laws in Poland after World War II. Even today, an influential political force - the intelligentsia - continues to treat the church with distrust as an alien power that also interferes with state life. And looking back, it is clear that this minority has disagreed with the rule of Catholicism for centuries.

During the period of the Second Polish Republic (1918-1939), speeches against the church of certain population groups occurred as often as during periods of domination of foreign political regimes on the territory of Poland. However, in the interwar period, the state and the church generally coexisted in harmony. They entered into mutually beneficial agreements that constrained the Roman Catholic Church's anti-regime performances as a recognized national denomination. "Even under favorable conditions, Caesar and the Lord are not the best partners," the Poles said, citing the rule of Roman law [ ${ }^{5}$, s. 160].

3 Єленський В. Є. Релігійно-суспільні зміни в посткомуністичній Європі / В. Є. Єленський // Людина і світ. - 1999. - № 7. - С. 30-33.

${ }^{4}$ Государства и религии в Европейском Союзе (опыт государственно-конфессиональных отношений) / Под ред. Г. Робберса. - М. : Институт Европу РАН, 2009. - 719 с.

5 Religiöser Wandel in den postcommunistischen Landern Ostund Mitteleuropas. Wurzburg, 1998. - $176 \mathrm{~s}$. 
The 20-30s in Poland were characterized by intra-state confrontations, disputes between the government and the Vatican, the government and certain segments of the population regarding the attitude of the Holy See to the possible independence of Poland in church and religious aspect, since the Vatican ruling top did not want to influence life of the Polish public, wished to keep the Poles in subjection to obedience to the official Catholic doctrine. In turn, the government, under the reign of J. Pilsudski, was negative about the Vatican's desire to enslave the people because of the domination of religion and the church in the state, and the ruling top Catholic priests to govern the state and the people. Realizing this, the Pope changed his policy and supported Y. Pilsudski, which slightly weakened the confrontation between officials and the religious leadership, but some of the influential representatives of the church remained forever opposed to the marshal $\left[{ }^{6}\right.$, s. 200-201].

Although the legal framework was borrowed from the Soviet Union in the late 1940s, the Church's profound influence on the social and political life of the Poles could not be ignored when new laws were passed. In socialist Poland, the land was left in the possession of the church, parishes and monasteries were allowed to have up to 50 hectares of land, the state government financially subsidized religious associations and paid wages.

The system of separation of church and state could not be implemented by a single act. The process was initiated by the Manifesto of the Polish Committee of National Liberation on June 22, 1944, and the specific foundations of the political policy of the People's Republic of Poland were reflected in the 1952 Constitution $\left[{ }^{7}\right]$, which abolished the concordat and stated that relations between the state and the church were determined exclusively by the state laws. Article 69 of the Constitution guaranteed citizens, regardless of their attitude to religion, equal rights in all spheres of political, economic and cultural life. The state has declared protection of the freedoms of believers and atheists. It should be noted that the forms of this regulation were too general and symbolic. This resulted in the freedom of conscience not being fully guaranteed by the action of specific legal mechanisms, which gave rise to many difficulties in implementing its principles. The country's church was not endowed with legal personality [ ${ }^{8}$, s. 127$]$. Similar shortcomings occurred in the Constitution of the People's Republic of Poland in 1976; the main one was the

${ }^{6}$ Tretera J. R. Church and State in the Czech Republic / J. R. Tretera // European Journal for Church and State Research. - Peeters, Leuven. - 2001. - Vol. 8. - P. 287-294.

${ }^{7}$ Конституция и основные законодательные акты Польской Народной Республики. Пер. с польского. - М. : Политиздат, 1953. - 420 с.

${ }^{8}$ Krukowski J. Problematuka osobovosci prawnej kosciola katolickiego w relacji do panstva / J. Krukowski // Roczniki teologiczno-kanoniczne / Kom. Red. : T-wo nauk. Katolickiego uniw. Lubelskiego. - Lublin, 1978. - S. 122-146. 
non-recognition of the legal personality of a legal entity by the church $\left[{ }^{9}\right]$. This did not correspond to the real status of the church in the state, so there were frequent conflicts on this basis. The authorities of Poland have made a mandatory oath for priests $\left[{ }^{10}\right.$, p. 123]. Following the example of an "elder brother", a state body, the Ministry of Religious Affairs under the Cabinet of Ministers of the People's Republic of Poland, was created to monitor the observance of legislation on religion and the church.

In terms of the relationship of religion and church Poland declared principle of the secular nature of the state and neutrality with respect to the outlook of its citizens. Socialist countries generally (with the exception of Albania) recognized freedom of conscience and religion up to the right to spread religious or atheistic views. These ideas were reflected in the Constitutions of the Warsaw Pact [See: ${ }^{11}$ ]. In practice, the peculiarity of state-church relations in socialist countries was the subordination of religious policy to official ideology. The result was a contradiction between constitutional theory and real life. The state, using various means of coercion, restricted freedom of conscience and religion. In the Polish Constitution and legislation on religious freedom, the rights of religious associations narrowed mainly to the function of satisfying religious needs in prayer houses. Cultural, educational and other activities were banned. The Constitution of the People's Republic of Poland formally, symbolically regulated the state-church relations. In declaring freedom of conscience and religion, the Basic Law of the Polish Republic did not indicate the specific rights of citizens that should follow from the proclaimed freedom, and the law did not recognize the rights of legal entities under ecclesiastical organizations. It is no coincidence that $69 \%$ of Poles positively evaluate the role of the church that it played during the communist regime. However, in 1989-1993 the number of critics of the church increased; $50 \%$ of respondents accused it of "interfering in politics" [ $\left[{ }^{12}\right.$, s. 157-169].

In the 1980s, religious movements and communities associated with the Catholic Church developed in Poland. In the late 1980s, religious movements of a sectarian nature began to develop widely. Some of them called themselves Christian, others were inspired by the religions of the East, while others became

9 Сленський В. Є. Релігійно-суспільні зміни в посткомуністичній Європі / В. Є. Сленський // Людина і світ. - 1999. - № 7. - С. 30-33.

10 Юскаев Н. Х. Из опыта взаимодействия армии и церкви в некоторых восточноевропейских странах / Н. Х. Юскаев // Религия, церковь в России и за рубежом: Информационно-аналитический бюллетень. - 1998. - № 3-4. - С. 120-129.

11 Конституции социалистических государств. - В 2-х т. - М. : Юридическая литература, 1987. - Т. 1;2.

12 Religiöser Wandel in den postcommunistischen Landern Ostund Mitteleuropas. Wurzburg, 1998. - $176 \mathrm{~s}$. 
echoes of existing socio-political ideologies. Often they offer substitutes and symbolic equivalents of religious experience. Activities of sects and new religious movements are carried out mainly in selected social groups of strategic importance (for example, among young people). The expansion of new religious movements continued in the $1990 \mathrm{~s}\left[{ }^{13}\right.$, p. 110-111]. Against this background, the new social situation has led to the need to think about what is religion and what is not, as well as a partial departure from the theories and methods to religion's sociology of that time.

The communist period is well characterized by the metaphor of the church as being "surrounded by a stronghold." At the same time, this did not mean identifying all Catholics with the official model. Poland also experienced a virtually inconspicuous and fragmentary modernization, which also caused changes in religiosity: selectivity in adopting faith and observing moral Catholic norms, especially in the area of rituals and customs. The presence of such features of religiosity leads to the conclusion that there has been an implicit privatization of religion after the Second World War in Poland $\left[{ }^{14}\right.$, p. 223-233]. The church has transformed with a great deal of public respect and trust; This is evidenced by the fact that in the socialist state in the $1980 \mathrm{~s}$, according to various polls, about $80 \%$ of the population declared their belief that the church was properly serving the public interest. The internal tensions in the church environment related to Catholic reform figures were unknown to the general public. There has been no public debate on religion, church or morality. The Church appeared to be a strong, compact, emphatic clerical authority (as opposed to a weak and powerless worldly community), disciplined, with a hierarchical structure $\left[{ }^{15}\right.$, s. $22-23 ;{ }^{16}$, s. 12$]$.

The anti-communist movement in Poland and the associated "religious thaw" took on a new dimension after the event that took place in Rome in late 1978: the election of Cardinal Pope John Paul II. The following year, the Herek regime allowed his visit to his homeland. The celebrations, which were attended by huge crowds, provided the Union's intellectuals, workers, and churches with a new, nationwide, patriotic and ethical dimension. The people also realized their power against the party and the state apparatus, which could do nothing but

13 Маріянський Я. Суспільний характер релігії / Я. Маріянський // Релігія в сучасному світі: Матеріали до курсу релігієзнавства / За ред. Г. Зімоня. - Переклад 3 польської Г. Теодорович. - Л. : Свічадо, 2007. - 504 с. - С. 97-125.

${ }^{14}$ Borowik I. Odbudowanie pamięci. Przemiany religijne w środkowo-wschodniej Europie po spadku komunism / I. Borowik. - Krakow : Zakład Wydawniczy NOMOS, 2000. - 248 s.

${ }^{15}$ Gowin Por. J. Kościół po komunizmie / J. Por. Gowin // Znak. - Kraków, 1995. - S. 22-23.

${ }^{16}$ Piwowarski W. Socjologia religii / W. Piwowarski. - Lublin: Redakcja Widawnictw Katolickiego Uniwersytetu Lubelskiego, 1996. - 98 s. Pravo Wyznaniowe. Ustawa z dnia 17 maja 1989 r. O gwarancjach wolności sumienia i wyynania. - Warszawa, 1989. - 396 s. 
small oppression. "During the papal visit," says American historian of Polish descent P. Wandicz, "Poland was another, was a free country" [ ${ }^{17}$, p. 322 - 323].

This landmark event in the history of Poland created new conditions for the regulation of state-church relations. In the early 1980s, the authorities began to eliminate obstacles to religious freedom. The result was a revival of religious life, which led to an increase in the number of religious communities, the construction of new religious buildings, the liberalization of legislation on freedom of conscience and the activities of religious organizations.

In 1980-1981, Polish believers were given the opportunity to regularly listen to the worhip on the state radio network. A joint commission has been set up between the government and the Episcopate to work on the legal settlement of the problematic issues. The Polish government, under pressure from the opposition, was forced to take the initiative to formally negotiate with the leadership of the Roman Catholic Church in order to determine the status of the latter in the state. The negotiations lasted for several years and resulted in the adoption on May 17, 1989 of three laws: "On the Relations between the State and the Roman Catholic Church"; "On Guarantees of Freedom of Conscience and Religion"; "On the social security of the clergy." The content of these laws has been brought into line with the country's international human rights obligations [ ${ }^{18}$, p. 154]. The Church of Poland became a powerful force, playing an important role in the preparation of the 1989 peace revolution. According to the publicist E. Sardykowski, the church in the life of the Polish people was, "firstly, a national flag, secondly aimed at Marx, and thirdly, the only testimony of truth and freedom" [Cite: ${ }^{19}$, p. 13]. Poland was the first country in the socialist camp to adopt a package of documents, which was an important step towards the promotion of democracy, civil rights and freedoms $\left[{ }^{20}\right.$, p. 9].

It is noteworthy that Poland became the first Eastern European country to consolidate at the constitutional level the right of citizens to replace military service. In June 1988, the Seimas of Poland introduced a new form of military service - a replacement alternative service. In January 1991, the decree of Pope John Paul II restored the Polish military hierarchy. The congregation of bishops

${ }^{17}$ Вандич П. Ціна свободи. Історія Центрально-Східної Свропи від Середньовіччя до сьогодення / П. Вандич. - К.: Критика, 2004. - 463 с.

18 Овсиенко Ф. Г. Взаимоотношения государства и церкви в странах Восточной Европы / Ф. Г. Овсиенко // Мировой опыт государственно-церковных отношений : Учебное пособие / Под общ. ред. Н. А. Трофимчука. - М. : Изд-во РАГС, 1998. - 306 с.

${ }^{19}$ Конотоп Л. Г. Головні характеристики містики: структура і зміст (в контексті релігійної антропології) / Л. Г. Конотоп, В. Л. Хромець // Антропологічні виміри езотеричної філософії. - Слов'янськ Печатний двір, 2005. - С. 43-51.

20 Барнакевич Ю. Правовые основы гарантий свободы совести в Польской Республике: Автореф. дис. ...канд. филос. наук / Ю. Барнакевич. - М., 1990. - 22 с. 
approved the statute of the Polish diocese $\left[{ }^{21}\right.$, p. 288]. Chaplains are a separate corps of servicemen, led by the Chief Field Bishop [ ${ }^{22}$, p. 168].

Legal principles of state-confessional relations in the new postcommunist conditions, the scope of the rights of believers were defined by the Law of the Polish Republic of "On guarantees of freedom of conscience and religion [ ${ }^{23}$, s. 347-368], May 17, 1989, as amended on June 26, 1997. In accordance with Article 1, the Republic of Poland guarantees to every citizen the freedom of conscience and religion, which is the freedom to choose religion and religious beliefs, their expressions individually and collectively, private and public. Believers of all religions, as well as non-believers, have equal rights in state, political, economic, social and cultural life. The government promotes religious denominations and creates no obstacles to their activities. In accordance with the law and the norms of the Constitution, citizens have the right: to establish religious communities (churches and other religious organizations) in order to recognize and spread the religious faith; participate in religious activities and ceremonies as well as perform religious duties and celebrate religious holidays; to spread their religion and beliefs, to educate their children according to their own beliefs in the religious spirit; not to disclose their religious preferences; to participate in the work of international religious organizations; use sources of information on religion; produce and buy items needed for religious purposes and religious ceremonies; to become a priest or a monk; to be buried in accordance with a religious ritual or belief. But the law also provides for restrictions imposed by the state in the exercise of these rights, as evidenced by Article 3: "Individual or collective expression of one's religion or belief may be restricted by law only in the interests of public safety, order, health or morals of the population or legal rights and freedoms of others. Freedom of conscience and religion may not be a cause of release from the performance of public duties required by law" $\left[{ }^{24}\right.$, s. 350].

Thus, Poland has now become a religiously and ideologically pluralistic country. However, this pluralistic denomination of faiths and a certain circle of unbelievers do not weaken the eloquent phenomenon of the vast majority of Catholics in the country. 95\% (according to other 89\%) of the 2 million inhabitants are Roman Catholics, ie even more than those who profess their

${ }^{21}$ Мировой опыт государственно-церковных отношений : Учебное пособие / Под общ. ред. Н. А. Трофимчука. - М. : Изд-во РАГС, 1998. - 306 с.

22 Овсиенко Ф. Г. Взаимоотношения государства и церкви в странах Восточной Европы / Ф. Г. Овсиенко // Мировой опыт государственно-церковных отношений : Учебное пособие / Под общ. ред. Н. А. Трофимчука. - М. : Изд-во РАГС, 1998. - 306 с.

${ }^{23}$ Rahner K. Atheismus / K. Rahner // Sacramentum mundi. Theologisches Lexikon für Praxis. - Bd1/Hrsg K. Rahner, A. Darlap. - Freiburg, 1967. - S. 372-383.

${ }^{24}$ Rahner K. Atheismus / K. Rahner // Sacramentum mundi. Theologisches Lexikon für Praxis. - Bd1/Hrsg K. Rahner, A. Darlap. - Freiburg, 1967. -S. 372-383. 
faith in God. Therefore, the Catholic Church was and remains a reputable spiritual power in Poland's political arena. It has a strong branched infrastructure that has evolved even in communist times. The number of priests (nearly 30,000) allows the church to send missionaries to countries in Europe, Asia, Africa and America [ ${ }^{25}$, p. 447].

In Hungary, as in most countries of Central and Eastern Europe, in the late 1940s, a state system of a totalitarian type, mounted on a Soviet bastard, prevailed. This system was immediately doomed to permanent socio-political crises.

Having seized power with the help of the Soviet special services in March 1948, the Hungarian Communists under the leadership of M. Rakoshi, the leader, abolished democratic institutions - human rights and the rule of law. In Hungary, the increasingly severe restriction of religious activity in 1945-1948 changed to brutal terror against the Catholic Church. In 1948, the head of the Church of Cardinal Jozef Mindsenti was arrested and convicted on charges of "anti-state activity" $\left[{ }^{26}\right.$, p. 160]. They made mass arrests, suppressed the slightest manifestation of dissent. "Enemies" were searched and "found" even among the communist leadership. An atmosphere of fear and oppression prevailed in the country $\left[{ }^{27}\right.$, p. 101]. Following the example of the "elder brother," the local nomenclature significantly restricted the activities of the churches and the prerogatives of the clergy. The church was not to go beyond the altar and the confessional. In accordance with the new requirements for the appointment of bishops of the Catholic, Evangelical and Reformed churches, the prior consent of the Presidium of the Hungarian People's Republic was required. For appointment to other ecclesiastical positions, the prior consent of the State Administration for Religious Affairs - controlled by the special services of the bureaucratic body - was required $\left[{ }^{28}\right.$, p. 442].

Many issues of state-church relations in Hungary were resolved by concluding treaties between the state and specific churches: the Reformed (October 7, 1948), Lutheran (December 14, 1948), and Catholic (August 30, 1950). Pursuant to these agreements, churches in the country could, on a limited scale, carry out religious and outreach activities, engage in missionary and

${ }^{25}$ Рынковский М. Государство и церковь в Польше // Государства и религии в Европейском Союзе (опут государственно-конфессиональнух отношений) / Под ред. Г. Робберса. - М. : Институт Европы РАН, 2009. - 719 с. - С. 447-470.

${ }^{26}$ Бураков Ю. В., Кипаренко Г. М., Мовчан С. П., Мороз Ю. М. Всесвітня історія. Новітні часи. 1945-1996 : Підручник. - К. : А.С.К., 1998. - 320 с.

${ }^{27}$ Шанда Б. Государство и церковь в Венгрии / Б. Шанда // Государства и религии в Европейском Союзе (опут государственно-конфессиональнух отношений) / Под ред. Г. Робберса. - М. : Институт Европу РАН, 2009. - 719 с. - С. 97-126.

${ }^{28}$ Палінчак М. М. Держава і церква у постсоціалістичних суспільствах (на прикладі країн Центральної Європи та України): Монографія. - Ужгород: Поліграфцентр «Ліра», 2014. $-408 \mathrm{c}$. 
charitable activities, receive financial assistance from the state, etc. Religious education in public schools was allowed only on an optional basis $\left[{ }^{29}\right.$, p. 442].

The death of Stalin in 1953 and the beginning of the political thaw in the USSR had a positive impact on developments in the countries of Central and Eastern Europe. The communist leaders of the satellite countries were forced to carry out some, albeit bold and inconsistent, liberalization of the political course, which somewhat reduced the level of discontent and indignation of the mainstream regimes, but not everywhere.

The 20th Congress of the CPSU (1956) had an even greater influence on the European countries of "popular democracy, and criticism of the "cult of person" that was discussed there, was the first attempt to tell tell the truth about the Stalin's horrific crimes". Impressed by these developments, a broad democratic movement began in some countries of Central and Eastern Europe, whose members demanded the establishment of civil and political rights and freedoms, and the cessation of the slave-copying of the Soviet "experience." Given the specific conditions of totalitarian regimes, the reform supporters were forced to adhere to a "socialist" framework, calling only for the elimination of "distortions" of Leninist principles. The political situation in the countries of Central and Eastern Europe has escalated sharply, and a sharp political crisis has emerged in Poland, Hungary and the GDR. In Poznan (Poland), in June 1956, workers and youth rebelled. The suppression of this speech caused a new wave of outrage in the country. In autumn Poland was on the verge of a nationwide explosion. He managed to avoid it by changing the party-state leadership and sharpening the political course from rigid, repressive, to liberal.

At the same time, a people's revolution began in Hungary on October 23, 1956, which immediately swept the entire country and within a few days swept the Stalinist regime. Hungary was ready to withdraw from the communist bloc and join the European family of free democratic states, but the Soviet leadership could not accept this and decided to take armed intervention. Soviet army forces invaded Hungary, bringing with them a new Hungarianpeasant government formed in Soviet territory. The revolution was cruelly suppressed. Hundreds of its members, including former Prime Minister I. Nagy, have been executed, and thousands of others have been sentenced to long-term imprisonment [See: ${ }^{30}$, p. $131-161 ;{ }^{31}$, p. 288].

${ }^{29}$ Палінчак М. М. Держава і церква у постсоціалістичних суспільствах (на прикладі країн Центральної Європи та України): Монографія. - Ужгород: Поліграфцентр «Ліра», 2014. -408 c.

${ }^{30}$ Бураков Ю. В., Кипаренко Г. М., Мовчан С. П., Мороз Ю. М. Всесвітня історія. Новітні часи. 1945-1996 : Підручник. - К. : А.С.К., 1998. - 320 с.

${ }^{31}$ Країнознавство. Країни СНД, Свропи і Північної Америки: Навчальний посібник / М. С. Дорошко, Р. А. Кривонос, В. П. Крижанівський, Н. Ф. Сербіна. - К. : Ніка-Центр, 2009. $-312 \mathrm{c}$. 
During the revolutionary events, the Catholic Church hierarch, Cardinal J. Mindsenti, actively spoke on the side of opposition forces that attempted to overthrow the political regime. After the defeat of the uprising, the cardinal was forced to seek political asylum at the US Embassy in Hungary, where he spent 15 years, and in 1971 left for Rome. After the suppression of the 1956 revolution, Hungarian society lost its internal strength to open resistance to political pressure. This moral surrender completed the process of social destruction.

Fortunately, political terror was not lasting. The leader of the reorganized Hungarian Socialist Workers' Party (USRP) and Prime Minister J. Kadar proved to be a figure with a broad outlook and a non-standard way of thinking. Without violating the principle of "loyalty" to the Soviet Union, he also pursued a moderately liberal course that is substantially different from the conservative policies that prevailed in the rest of the Eastern Bloc countries. Consumption of calories per capita has considerably increased. In Hungary in the 60-80s of the twentieth century, there was virtually no manifestation of political opposition and, accordingly, no persecution of dissenters by the authorities. The Hungarians were able to visit the free world freely. In general, this period in the history of the country was half-jokingly called "goulash socialism", referring to the attempts of the Hungarian party elite to build an industrial and at the same time consumer communist society, where everyone was guaranteed a goulash - a favorite Hungarian dish.

After Y. Kadar's speech at the newly elected Hungarian Parliament in the fall of 1962 and the concordat of the Hungarian People's Republic with the Vatican on September 15, 1964, it becomes possible to talk about the relative normalization of state-church relations in the "hottest barracks" of the Communist camp. Formation of a relatively liberal attitude of the authorities to religious institutions has been delayed in this country for decades. Despite some liberalization of the regime, Hungarian religious scholars and sociologists state: Hungary experienced a deep religious decline in the 1960s and 1970s and an unexpected but steady increase in the religiosity of all ages since the late 1970s.

Some revival of religious life in the country was primarily due to the entry into the historic arena of the new generation. Its economic base was made up of small private businesses in agriculture and in the third sector of the economy. It found ideological support from religion, which upheld public relations. The end of the 1970s was a period when an exclusively rural and poorly educated church, the main contingent of which consisted of elderly parishioners, began to recede into the past. Those who secured religious revival (residents of cities and youth) had higher educational level and participated more actively in public life $\left[{ }^{32}\right.$, p. 2-10].

\footnotetext{
${ }^{32}$ Релігія і релігійність у посткомуністичній Європі. Цифри і факти без інтерпретацій // Людина і світ. - 1997. - Листопад-грудень. - С. 2-10.
} 
The collapse of communism in the late 1980s gave rise to new freedom and new problems. Finding a new place in Roman Catholic, Greek Catholic, Reformed, and other churches was difficult, as decades of communist rule led to significant and violent secularization of Hungarian society [See: $\left.{ }^{33}\right]$.

Hungarian scholars say that, unlike Catholic Poland, the Church in Hungary is weak, and the confessional picture in this country is complex and confusing. In the 1990s, Hungarian society was ideologically divided into three parts. About a third of its representatives said they attend church worship, but only less than half practice it more or less regularlyThe second part (from 30\% to $40 \%$ ) sympathizes with traditional forms of religiosity, but does not participate in traditional and institutional cult practices. They claim to be believers, though they do not actually belong to churches. The last third of Hungarian society defines itself as non-believers and demonstrably distances itself from religion and the church. But those who define themselves as atheists make up only $4-5 \%$ of the adult population.

Adhering to democratic values, the post-socialist countries of Europe proclaimed freedom of conscience and religion as the basis for regulating stateconfessional relations. In the early 1990s, Hungary signed a number of international agreements related to religious freedom. In particular, the International Convention on Civil and Political Rights, the European Convention for the Protection of Human Rights and Fundamental Freedoms with its Additional Protocols, and other documents were signed and ratified [ ${ }^{34}$, p. 102-103].

According to the Constitution in the Republic of Hungary the church is separated from the state. The state cannot create bodies to check the activities of the church and its organizations. According to $\S 60$ of the Hungarian Constitution, the right to freedom of conscience and freedom of religion combines the free choice of religion and the free imitation of other religious beliefs. Everyone has the right to practice his or her religious beliefs alone or with a group of people, in public or in private (at home, in the circle of their loved ones). The constitutional provision stipulates that a Hungarian citizen has the right not only to practice but also to promote his or her religious beliefs. To spread religious or other beliefs of conscience, the law provides for the possibility of using the media $\left[{ }^{35}\right.$, p. 60].

The religious freedoms of citizens are also protected by the Criminal Code of the Republic of Hungary. According to the "violation of freedom of

${ }^{33}$ Центрально-Восточная Европа во второй половине ХХ века. - В 3-х т. - Т. 3 : Трансформации 90-х годов. - М. : Наука, 2002. - 516 с.

${ }^{34}$ Шанда Б. Государство и церковь в Венгрии / Б. Шанда // Государства и религии в Европейском Союзе (опыт государственно-конфессиональных отношений) / Под ред. Г. Робберса. - М. : Институт Европу РАН, 2009. - 719 с. - С. 97-126.

${ }^{35}$ Конституція України. - К., 1997. - 80 с. 
religion and religion" provision, any person who, through violence and threats, interferes with another person's freedom to practice his religion, commits a crime punishable by imprisonment for a term up to three years. Violence, humiliation and abuse of anyone because of their belonging to a national, ethnic or religious group is punishable by imprisonment for a term up to five years $\left[{ }^{36}\right.$, p. $\left.120-121\right]$.

In 1997, Parliament changed the system of state subsidies to churches. Back in 1990, the first freely elected parliament decided to provide financial assistance to religious organizations on a permanent basis. This meant that each year Parliament was forced to divide the "church fund" of the central budget between different churches and denominations, depending on the number of parishioners and the "social role" of religious organizations. However, the number of parishioners could not be determined. The idea of including the question of religious affiliation in the census questionnaire was declared unconstitutional. During 2012, the Hungarian government provided HUF 35 billion (approximately US \$ 161 million) in additional funding for churches to undertake a range of activities, in particular to support the public collection of works of art; support for religious education, education and culture; payment of annual compensation for non-reclaimed religious property ("eternal life annuity"); promoting the work of church staff serving the smallest villages. 4 "historical" churches continued to receive $93 \%$ of the total state financial support provided to religious groups $\left[{ }^{37}\right.$, p. 2].

Thus, the fall of the communist regime, the change in the legal system affect the state-church relations in the Republic of Hungary. Changes to the basic legislation on freedom of conscience have led to the expansion of the confessional spectrum of existing religious associations. The nature of the activities of religious organizations changed significantly. Nowadays it includes not only cult practice but also social, cultural, educational and entrepreneurial activity. This has greatly expanded the field and the scope of interactions between the state, religious organizations, and the possibilities of their legal support. Religious influence is evident in education, armed forces, in the political life of the Republic of Hungary.

An analysis of the norms of the Constitutions of Hungary and other postcommunist states, as well as of international documents of a universal nature, shows that in the individual dimension the right to freedom of thought, conscience and religion covers the following freedoms:

- whether or not to profess religion or belief;

${ }^{36}$ Шанда Б. Государство и церковь в Венгрии / Б. Шанда // Государства и религии в Европейском Союзе (опыт государственно-конфессиональных отношений) / Под ред. Г. Робберса. - М. : Институт Европу РАН, 2009. - 719 с. - С. 97-126.

${ }^{37}$ Budapester Zeitung. - 2013. - 10 Januar. - S. 2. 
- have or have no religious education;

- to participate or not to participate in any form of worship, not to be directly or indirectly compelled to disclose their beliefs, to have free access to places of worship;

- not to give any oaths contrary to human beliefs;

- express their religious beliefs openly or declare no religious beliefs;

- not to perform military service with weapons if it is contrary to human beliefs, instead undergo alternative civilian service.

Collectively, the right to freedom of thought, conscience and religion includes the following freedoms:

- freedom to express their beliefs and to spread their religious beliefs, while protecting each person and group from coercion, the opportunity to spread their beliefs, and to practice the customs of their religion without the intervention or invasion of outsiders;

- freedom to form religious associations that may be registered in the general register of legal entities or in the register of religious organizations in order to obtain the legal status and rights of the legal entity; at the same time, unions of believers may operate without official registration;

- the freedom to acquire and hold places of worship, to hold and attend religious worships and events;

- freedom to create and govern religious organizations on the basis of self-government, as well as to communicate with other national or international associations of believers;

- produce, buy, import, export and distribute religious literature, printed and audiovisual material or objects used in religious activities;

- establish and manage private schools, and engage in educational, cultural, philanthropic and social activities;

- seek and obtain voluntary financial assistance from individuals and institutions to support their activities.

Therefore, in the process of socio-political transformation in Hungary, due to the developed culture of political consensus and the rapid revival of civil society structures, the process of socio-political structuring took place organically. In view of this, a stable modern European democratic political system has been established in the country. In the summer of 2000, the Hungarians celebrated the 1000th anniversary of statehood. A symbol of Hungary's special role in the civilizational dialogue between the West and the East was the recognition of King Istvan (Stefan), who is a Catholic saint, also as an Orthodox saint $\left[^{38}\right.$, p. 211].

${ }^{38}$ Кріль М. М. Історія країн Центрально-Східної Свропи (кінець ХХ т. - початок XXI ст.) : Навчальний посібник / М. М. Кріль. - К. : Знання, 2008. - 284 с. 
Another country that had a communist influence on state-church relations was Czechoslovakia. At the end of World War II, the Catholic Church in Czechoslovakia was almost destroyed. At the same time, having failed to revive a little after the Nazi occupation, it fell again under the wrath, but now under communist one. It is striking that Muscophile-minded President Benesch "brought Russia and communism to the borders of his state" $\left[{ }^{39}\right.$, p. 177].

After the communist revolution in February 1948, the so-called "scientific", Marxist-Leninist ideology based on atheism and the denial of God was introduced into all spheres of public life. During 1948-1989, atheism in Czechoslovakia actually played the role of state "religion". The ultimate goal of the regime was, of course, the complete elimination of religious associations. Relying on the notorious Stalinist thesis of the aggravation of class struggle during the construction of socialism, the leadership of the Communist Party of Czechoslovakia, like other Eastern European parties, used to repress the real and potential opponents of the regime by inflating the atmosphere in society. Religious institutions have come under close scrutiny by the authorities, special services agents have been infiltrated into the church administration, and religious dissidents have been subjected to repression. According to incomplete data, only during the period 1948-1953, more than 70,000 innocent people were repressed in Czechoslovakia. Almost all Catholic bishops were either arrested, sent to concentration camps, or expelled from the country - the situation changed only when the communist regime was overthrown in 1989The dictatorship in no way took into account the Modus Vivendi agreement signed in 1927 between representatives of the Czechoslovak government and the Holy See. It concerned the process of appointing bishops in the country and guaranteed mutual respect for the interests of both parties [See details: ${ }^{40} ;{ }^{41}$, p. $264-265 ;{ }^{42}$, p. $118-120$ ]. In fact, relations with the Vatican were severed.

In addition, the CCP sought to undermine the authority of the church through the so-called Catholic Action and Pacem in Terris, and also aimed at the venerable Archbishop of Prague-Beran. The archbishop was first isolated at his residence and later taken to a monastery. In 1951, due to the fierce pressure, nine out of thirty bishops and most of the lower clergy swore to be loyal to the new regime $\left[{ }^{43}\right.$, p. $\left.47-50\right]$.

${ }^{39}$ Vaško V. Kronika katolickě cirkve c Českoslovnsku po druhě světove válce / V. Vaško. Praha, 1990. $-231 \mathrm{~s}$.

${ }^{40}$ Kaplan K. Stát a cirkev v Českoslovnsku v letech 1948-1953 / K. Kaplan. - Brno : Doplněk, 1993. - 121 p.

${ }^{41}$ Kováč D. Dejiny Slovenska / D. Kováč. - Praha: Lidové noviny, 1998. - 401 s.

${ }^{42}$ Vaško V. Kronika katolickě cirkve c Českoslovnsku po druhě světove válce / V. Vaško. Praha, 1990. - $231 \mathrm{~s}$.

${ }^{43}$ Kaplan K. Stát a cirkev v Českoslovnsku v letech 1948-1953 / K. Kaplan. - Brno : Doplněk, 1993. - 121 p. 
The foundations of a qualitatively new level of state-church relations in the modern Czech Republic were laid by the events of November 1989, which became known as the "Gentle" ("Velvet") revolution. The dynamics of change in Czechoslovakia were unprecedented: by the fifth day of the revolution, the "defense strategy" of the leaders of the Communist Party of Czechoslovakia had collapsed. One Western journalist aptly remarked: "Something that took the Poles ten years, the Hungarians ten months, the citizens of the GDR ten weeks, the Czechs and Slovaks carried out in ten days!" [ ${ }^{44}$, p. 194]. The Communist Party, devoid of the confidence and support of the people, was quickly removed from government. The wave of popular indignation dropped it from the administrative-leadership throne, which it took once by itself and failed to confirm its rights. The autumn events of 1989 in Czechoslovakia were not accidentally called the "gentle revolution". Many thousands of demonstrations took place in a very organized manner, with a radical political turn in the country with almost no excesses. This happened mainly due to the existence in society of certain democratic traditions and rudimentary public structures (although very ghostly ones), a high degree of readiness for change of the population of the country, which was well aware of the hopelessness and foreignness of the imposed socio-political system.

The Velvet Revolution became a point of departure, signaling positive changes in the mutual relations of the state and religious organizations. The revolution found widespread support from the church and religious organizations $\left[{ }^{45}\right.$, p. 142]. Cardinal F. Tomaszek openly declared that he and the Catholic Church stand on the side of the people [ $\left.{ }^{46}, \mathrm{p} .17\right]$.

The Prague government has started a new church-state relations with the unsuccessful attempts to create a "national Catholic Church," which would have to break off relations with the Apostolic Capital. But in reality, government policy has led to the formation of parallel structures in the church and the emergence of dissident priests who have acted illegally without obtaining the permission of the authorities or the state content granted to registered clergy. The presence of priests of the so-called "catacomb church" has become a problem that the Vatican has failed to solve throughout the decade since the fall of communism. Even the visit of Pope John Paul II to the Czech Republic in May 1995 did not help in this case. Several Czech bishops, at one time,

${ }^{44}$ Історія Чехії очима українців : Навчально-популярне видання. - Ужгород : Гражда, 2009. -224 c.

${ }^{45}$ Cepliková M. K niektorým aspektam právnej úpravy vzt'ahov štátu a náboženských organizácii na našom územi po roku 1989 / M. Cepliková // Právny obzor: Bratislava. - 1999. № 2. - S. 140-147.

${ }^{46}$ Szostkiewicz A. Religion after Communism / A. Szostkiewicz // Commonweal. 09/24/99. - Vol. 126. - Issue 16. - P. 17-34. 
consecrated laymen with violations of the canon law of the Roman Catholic Church (celibacy, etc.), based on the real situation of state pressure. Only at the beginning of 2000 Congregation for the Doctrine of the Faith has given a final assessment of the situation in the Czech Republic, pointing out that Czech Catholics are members of the "Catacomb Church", they are not persecuted like the first Christians and must adhere strictly to the canon law. The tension between Prague and the Vatican can be explained by the following fact. During 2000-2002, representatives of the Czech Republic and the Apostolic Capital drew up an international agreement signed by them in June 2002. However, the House of Representatives by 110 votes to 90 did not recommend the government ratify the treaty, delaying its consideration until "more favorable times." [ ${ }^{47}$, c. 639-640].

Immediately after the "velvet" revolution, all anti-church articles of the Criminal Code and the legislative norm of communist times were abolished, which allowed the state to interfere in the process of appointment and approval of the clergy, preachers, and all ministers of the church. This principle was also confirmed in the Parliament and adopted by the Czech and Slovak Federal Republic (CSFR) on January 9, 1991 of the Charter of Fundamental Rights and Freedoms, which became an important part of the constitutional order of the Czech Republic. $\left[{ }^{48}\right.$, c. 486$]$.

Summing up, it should be noted that the state-church relations in the Czech Republic settled in accordance with international law. The state has done much to eliminate the recurrence of Czechoslovakia's communist regime's policies on religion and the church. A specific feature that has historical roots is a weak link between the majority religion and the national archetype and a low percentage of believers. It should also be noted that there has never been a regime of complete and rigid separation of the church from the state in the Czech Republic. Currently, the state adheres to the principle according to which it does not identify itself with any church, and the principle of equality and autonomy of churches. However, the state cooperates with churches in many areas. Church law specialists call this model of state-church relations cooperative [ ${ }^{49}$, p. 287-294].

It should be noted that by far the most tragic period in the history of the church on Slovak teritory was the communist one (1945-1989). The Catholic

47 Третера И. Р. Государство и церковь в Чехии / И. Р. Третера // Государства и религии в Европейском Союзе (опыт государственно-конфессиональных отношений) / Под ред. Г. Робберса. - М. : Институт Европы РАН, 2009. - 719 с. - С. 631-656.

${ }^{48}$ Конституція Чеської Республіки // Конституції нових держав Європи та Азії / Упорядник С. Головатий. - К. : Українська Правнича Фундація, вид-во «Право», 1996. $612 \mathrm{c}$.

${ }^{49}$ Tretera J. R. Church and State in the Czech Republic / J. R. Tretera // European Journal for Church and State Research. - Peeters, Leuven. - 2001. - Vol. 8. - P. 287-294. 
and Greek Catholic churches of Slovakia, which were a bone in the throat for the communist regime, in 1949 came under total state control. A year later, a national security campaign began, during which the monasteries were abolished overnight, and the monks were interned in "forced labor camps." The monasteries were soon liquidated. The terrorist regime tried to intimidate the church with loud political processes over bishops Ya. Voitashak and M. Buzalko. Y. Voitashak was sentenced to 24 years in prison and M. Buzalka to life imprisonment. The trial of Greek-Catholic Bishop P. Goydic, who was sentenced to life imprisonment, was closely linked to the Kremlin's liquidation by order of the Greek Catholic Church in Slovakia. The Orthodox Church became the owner of all its temples and property, and the Greek Catholics converted to the Orthodox faith of the Moscow model. $\left[{ }^{50}\right.$, s. $\left.264 ;{ }^{51} ;{ }^{52} ;{ }^{53}\right]$.

Many Slovaks and Ukrainians escaped repression by fleeing abroad. Emigration to Western Europe, the United States and Canada has been increasing.

In the short term, the communist government eliminated all the germs of civil society. The citizen was to become an obedient executor of the will of an "infallible" political party, which taught him how to live, what to believe, where to go, what heroes to honor. The foundation of the pyramid of communist power in the countries of "real socialism" was undoubtedly the secret police - the state security service. In the shortest possible time, it has built an extensive network of agents and staff, whose primary responsibility was to report on any manifestations of citizen dissatisfaction with the party's policies and the potential foci of organized resistance, including the church environment $\left[{ }^{54}, \mathrm{~s} .264-265\right]$.

In April 1950, the so-called Presov Cathedral was held, which in fact led to the destruction of the Greek Catholic Church for several decades. The Council adopted a notorious act on the return of Greek Catholics to the bosom of the Roman Catholic Church, authorized by the Central Committee of the Communist Party of Slovakia on the basis of a resolution of January 7, 1950. Under the influence of the Prague Spring of 1968, which was to demonstrate to the world "socialism with a human face" and promote a new liberalization of the regime, Bishop V. Hopko asked O. Dubchek, who soon became secretarygeneral of the Communist Party, to rehabilitate and restore the activities of the church. However, Government Decree No. 70 of June 13, 1968, signed by the

${ }^{50}$ Kováč D. Dejiny Slovenska / D. Kováč. - Praha: Lidové noviny, 1998. - 401 s.

${ }^{51}$ Čikeš R. Vztahy štátu a cirkvi na Slovensku / R. Čikeš. - Bratislava : Ústav pre vzt'ahy štátu a cirkvi, 2010. $-90 \mathrm{~s}$.

${ }^{52}$ Kaplan K. Stát a cirkev v Českoslovnsku v letech 1948-1953 / K. Kaplan. - Brno : Doplněk, 1993. - 121 p.

${ }_{53}$ Pešek J. Štátna moc a cirkvi na Slovensku 1948-1953 / J. Pešek, M. Barnovský. Bratislava: VEDA, 1997. - $76 \mathrm{~s}$.

${ }^{54}$ Kováč D. Dejiny Slovenska / D. Kováč. - Praha: Lidové noviny, 1998. - 401 s. 
Head of the Government of Czechoslovakia, G. Husak, banned again the activities of the Greek Catholic Church [ ${ }^{55}$, p. 124-139].

The highest authority implementing the Czechoslovakia Communist Party (CZCP) policy was established in 1949 by the State Committee on Church Affairs (SCCA), and in Slovakia by the Slovak Church Government. The "war on religious remnants" policy was elaborated and formulated in the highest party organs, in particular in the so-called Church Commission of Central Committee of the CZCP, which included six members, often referred to as the "Church Six." For many years, the Communist nomenclature, in the person of the SCCA, controlled the liturgical, pastoral, social, charitable, educational, financial and other spheres of activity of the churches. Mandatory registration of religious organizations was established, and the clergy were allowed to carry out their mission only on the basis of a state permit issued exclusively by "trustworthy", loyal to the regime persons. Illegal religious activities of individual worshipers and religious communities were severely prosecuted by state security agencies $\left[{ }^{56}\right.$, s. $\left.100-105\right]$.

Only after November 1989, when there was a "velvet" revolution, changes in the powerless position of churches and denominations have become part of social and political alterations. Churches have regained their independence, and at the same time they had great opportunities to strengthen their position in Slovak society. After the peaceful division of the Czech Republic and the Slovak Republic into two independent states, on January 1, 1993, the Slovak Republic appeared on the political map of the world. From that time on, the rights and freedoms of the individual and the citizen, their purpose, protection and guarantees have been established in it as the basic and determining criterion of the legal nature of the legislation and practice of its application. For each person preserves a certain set of natural inalienable rights, which are determined by the very fact of human existence and should be considered as a guarantee of its dignity.

According to Article 11 of the Constitution of the Slovak Republic, adopted in 1992, "international instruments on human rights and freedoms ratified by the Slovak Republic and promulgated in accordance with the law have priority over national laws, provided that international treaties and agreements guarantee a higher level of constitutional rights and freedoms" $\left[{ }^{57}\right.$, p. 446].

${ }^{55}$ Moravčiková M. Religiozita na Slovensku / M. Moravčiková, M. Cipár // Ročenka ústavu pre vzt'ahy štátu a cirkvi 1997. - Bratislava : Ústav pre vzt'ahy štátu a cirkvi, 1998. - $211 \mathrm{~s}$.

${ }^{56}$ Vaško V. Neumlcena kronika katolicke cirkve v Ceskoslovensku po druhe svetove valce / V. Vaško. - Praha, 1990. - 261 s.

${ }^{57}$ Конституція Угорської Республіки // Конституції нових держав Свропи та Азії / Упорядник С. Головатий. - К. : Українська Правнича Фундація, вид-во «Право», 1996. $612 \mathrm{c}$. 
The Constitution states that all people are free and equal in dignity and rights, and that fundamental rights and freedoms are inalienable and inviolable in the territory of the state. They are guaranteed to every person regardless of gender, race, color, language, religion and religion, political or other beliefs, national or social origin, nationality or ethnicity, property, family or other status. No one may be deprived of his legal rights, discriminated or privileged. The basic rights and freedoms of the human rights in the Constitution of Slovakia are set aside in Part II. The set of rights, freedoms and responsibilities enshrined into it is a system of constituents of personal, civil, political, social, economic, national minorities and ethnic groups, cultural and religious rights. The system of these constitutional norms defines the status of a person and a citizen in the Slovak Republic.

The international treaty, which regulates in general relations between Slovakia and the Holy See, was signed on November 24, 2000, and came into force after an exchange of instruments of ratification in the Vatican on December 18,2000 . The treaty officially entitles the Vatican through its sub-structure, the Catholic Church, to take part in the international affairs of the Slovak Republic, to provide benefits and privileges to the Catholic Church through the return to the churches of real estate, along with significant government subsidies and rights. For the Vatican it was a 184 agreement; from post-socialist countries, Poland, Hungary, Croatia, Yugoslavia, Lithuania, Estonia, Latvia, Kazakhstan and the Czech Republic have previously signed similar agreements [ ${ }^{58}$, p. 114].

The constitution and other laws of Slovakia generally protect religious freedom, although the Law on Registration of Religious Groups and Associations does some harm to smaller denominations. It determines the status of registered religious groups and contains registration requirements. To register a religious group, 20,000 of its adult members, who are either Slovak nationals or permanent residents of that country, they must submit to the Ministry of Culture an "honest declaration" that confirms their membership, knowledge of the articles of faith and basic principles of religion; it also includes identification numbers and home addresses. Registration provides the legal status necessary to perform economic functions, such as opening a bank account or leasing property, and religious functions, such as directing funeral ceremonies or accessing hospitalized peers. It should be emphasized that only officially registered communities are eligible for financial subsidies from the state. A total of 18 registered churches and religious groups received more than $€ 39$ million (about $\$ 40.1$ million) in state subsidies [ ${ }^{59}$, p. 170-184].

58 Šmid M. Priprava Základnej zmluvi medzi Slovenskou republikou a Svatou stolicou / M. Šmid // Ročenka Ústavu pre vzt'ahy štátu a cirkvi 1999. - Bratislava, 2000. - 187 s.

59 Палінчак М. М. Система державно-церковних відносин у посткомуністичній Європі: уроки для України / М. М. Палінчак // Соціогуманітарні проблеми людини : Вісник. 2012. - № 6. - С. 170-184. 
Therefore, each country of the designated region, in view of historically determined traditions, peculiarities of spiritual culture and mentality of the people, resolves the issue of state-church relations, guarantees of freedom of religion and its confessional institutionalization, tolerance of interfaith relations. Each state tries to create conditions to meet the religious needs of believers and society, and to give religious communities greater freedom of activity.

It has been proven that religious freedom is protected by the constitutions and laws of the states in question, and, as practice shows, governments generally respect religious freedom. The tendency for religious freedom to be respected by governments did not change significantly over the period under review. Governments continued to provide tax breaks and financial support to registered religious groups.

\section{CONCLUSIONS}

State - church relations of the countries of the world are an important topic of research. These relations are one of the important components of the domestic and foreign policy of the state. Thus, these relationships characterize the level, depth of relations between authorities and religious organizations, the degree of their integration (or disintegration) and cooperation. The history of church and state is almost always connected. State - church relations in the countries of Central Europe were no exception. Namely in Poland, Hungary, the Czech Republic and Slovakia.

Concerning the role of religious factor in the processes of national consolidation of society, on the basis of the above and analyzed material, it can be concluded that churches in the countries of Central and Eastern Europe (especially in Poland), even in the Soviet period, were officially recognized as an important factor in preserving national identity, in spite of all threats and dangers, they demonstrated much efforts in the field of raising public morality and patriotic education. The fact that churches, despite everything, have played a positive role in peaceful revolutions, accelerating the fall of the communist regime, confirms that totalitarian regimes always fail in their attempts to abolish religions. Moreover, anti-religious propaganda and persecution of believers indirectly worked for the authority of the churches.

At the beginning of the XXI century the church remains a reputable spiritual power in Central and Eastern Europe.

\section{SUMMARY}

The article deals with the development of state-church relations in the countries of Central and Eastern Europe. Constitutional legal and social status of church in Poland. Specificity of the Hungarian model of state-confessional relationships. Relations between the state and church in the Czech Republic. 
State-confessional relations in Slovakia. The role of the communist regime in the state-church relations of Central and Eastern Europe countries.

\section{REFERENCES}

1. Барнакевич Ю. Правовые основы гарантий свободы совести в Польской Республике: Автореф. дис. ...канд. филос. наук / Ю. Барнакевич. М., 1990. - 22 c.

2. Бураков Ю. В., Кипаренко Г. М., Мовчан С. П., Мороз Ю. М. Всесвітня історія. Новітні часи. 1945-1996 : Підручник. - К. : А.С.К., 1998. - 320 c.

3. Вандич П. Ціна свободи. Історія Центрально-Східної Європи від Середньовіччя до сьогодення / П. Вандич. - К.: Критика, 2004. - 463 с.

4. Государства и религии в Европейском Союзе (опыт государственно-конфессиональных отношений) / Под ред. Г. Робберса. М. : Институт Европы РАН, 2009. - 719 с.

5. Єленський В. Є. Релігійно-суспільні зміни в посткомуністичній Європі / В. С. Сленський // Людина і світ. - 1999. - № 7. - С. 30-33.

6. Історія Чехії очима українців : Навчально-популярне видання. Ужгород : Гражда, 2009. - 224 с.

7. Конотоп Л. Г. Головні характеристики містики: структура і зміст (в контексті релігійної антропології) / Л. Г. Конотоп, В. Л. Хромець // Антропологічні виміри езотеричної філософії. - Слов'янськ Печатний двір, 2005. - С. 43-51.

8. Конституции социалистических государств. - В 2-х т. - М. : Юридическая литература, 1987. - Т. 1; 2.

9. Конституция и основные законодательные акты Польской Народной Республики. - Пер. с польского. - М. : Политиздат, 1953. - 420 с.

10. Конституція Угорської Республіки // Конституції нових держав Свропи та Азії / Упорядник С. Головатий. - К. : Українська Правнича Фундація, вид-во «Право», 1996. - 612 с.

11. Конституція України. - К., 1997. - 80 с.

12. Конституція Чеської Республіки // Конституції нових держав Європи та Азії / Упорядник С. Головатий. - К. : Українська Правнича Фундація, вид-во «Право», 1996. - 612 с.

13. Країнознавство. Країни СНД, Європи і Північної Америки: Навчальний посібник / М. С. Дорошко, Р. А. Кривонос, В. П. Крижанівський, Н. Ф. Сербіна. - К. : Ніка-Центр, 2009. - 312 с.

14. Кріль М. М. Історія країн Центрально-Східної Свропи (кінець XX т. - початок XXI ст.) : Навчальний посібник / М. М. Кріль. - К. : Знання, 2008. - 284 c. 
15. Маріянський Я. Суспільний характер релігії / Я. Маріянський // Релігія в сучасному світі: Матеріали до курсу релігієзнавства / За ред. Г. Зімоня. - Переклад з польської Г. Теодорович. - Л. : Свічадо, 2007. 504 c. - С. $97-125$.

16. Мировой опыт государственно-церковных отношений : Учебное пособие / Под общ. ред. Н. А. Трофимчука. - М. : Изд-во РАГС, 1998. $306 \mathrm{c}$.

17. Овсиенко Ф. Г. Взаимоотношения государства и церкви в странах Восточной Европы / Ф. Г. Овсиенко // Мировой опыт государственно-церковных отношений : Учебное пособие / Под общ. ред. Н. А. Трофимчука. - М. : Изд-во РАГС, 1998. - 306 с.

18. Палінчак М. М. Система державно-церковних відносин у посткомуністичній Європі: уроки для України / М. М. Палінчак // Соціогуманітарні проблеми людини : Вісник. - 2012. - № 6. - С. 170-184.

19. Палінчак М. М. Держава i церква у постсоціалістичних суспільствах (на прикладі країн Центральної Європи та України): Монографія. - Ужгород: Поліграфцентр «Ліра», 2014. - 408 с.

20. Релігія і релігійність у посткомуністичній Європі. Цифри і факти без інтерпретацій // Людина і світ. - 1997. - Листопад-грудень. - С. 2-10.

21. Рынковский М. Государство и церковь в Польше // Государства и религии в Европейском Союзе (опыт государственно-конфессиональных отношений) / Под ред. Г. Робберса. - М. : Институт Европы РАН, 2009. 719 c. - С. $447-470$.

22. Третера И. Р. Государство и церковь в Чехии / И. Р. Третера // Государства и религии в Европейском Союзе (опыт государственноконфессиональных отношений) / Под ред. Г. Робберса. - М. : Институт Европы РАН, 2009. - 719 с. - С. 631-656.

23. Центрально-Восточная Европа во второй половине XX века. В 3-х т. - Т. 3 : Трансформации 90-х годов. - М. : Наука, 2002. - 516 с.

24. Шанда Б. Государство и церковь в Венгрии / Б. Шанда // Государства и религии в Европейском Союзе (опыт государственноконфессиональных отношений) / Под ред. Г. Робберса. - М. : Институт Европы РАН, 2009. - 719 с. - С. 97-126.

25. Юскаев Н. Х. Из опыта взаимодействия армии и церкви в некоторых восточноевропейских странах / Н. Х. Юскаев // Религия, церковь в России и за рубежом: Информационно-аналитический бюллетень. - 1998. - № 3-4. - С. 120-129.

26. Borowik I. Odbudowanie pamięci. Przemiany religijne w środkowowschodniej Europie po spadku komunism / I. Borowik. - Krakow : Zakład Wydawniczy NOMOS, 2000. - $248 \mathrm{~s}$.

27. Budapester Zeitung. - 2013. - 10 Januar. - S. 2. 
28. Cepliková M. K niektorým aspektam právnej úpravy vzt'ahov štátu a náboženských organizácii na našom územi po roku 1989 / M. Cepliková // Právny obzor: Bratislava. - 1999. - № 2. - S. 140-147.

29. Čikeš R. Vztahy štátu a cirkvi na Slovensku / R. Čikeš. - Bratislava : Ústav pre vzt'ahy štátu a cirkvi, 2010. - $90 \mathrm{~s}$.

30. Gowin Por. J. Kościół po komunizmie / J. Por. Gowin // Znak. Kraków, 1995. - S. 22-23.

31. Kaplan K. Stát a cirkev v Českoslovnsku v letech 1948-1953 / K. Kaplan. - Brno : Doplněk, 1993. - 121 p.

32. Kováč D. Dejiny Slovenska / D. Kováč. - Praha: Lidové noviny, 1998. $-401 \mathrm{~s}$.

33. Krukowski J. Problematuka osobovosci prawnej kosciola katolickiego w relacji do panstva / J. Krukowski // Roczniki teologicznokanoniczne / Kom. Red. : T-wo nauk. Katolickiego uniw. Lubelskiego. Lublin, 1978. - S. 122-146.

34. Moravčiková M. Religiozita na Slovensku / M. Moravčiková, M. Cipár // Ročenka ústavu pre vzt'ahy štátu a cirkvi 1997. - Bratislava : Ústav pre vzt'ahy štátu a cirkvi, 1998. - $211 \mathrm{~s}$.

35. Pešek J. "Katolická akcia" na Slovensku roku 1949 / J. Pešek // Historický časopis. - № 44. - 1996. - S. 47-63.

36. Pešek J. Konflikt medzi štátom a katolickou hierarchiou o prijatie a realizáciu "cirkevných zákonov" (19491951) / J. Pešek // Historický časopis. № 44. - 1996. - S. 444-470.

37. Piwowarski W. Socjologia religii / W. Piwowarski. - Lublin: Redakcja Widawnictw Katolickiego Uniwersytetu Lubelskiego, 1996. - $98 \mathrm{~s}$. Pravo Wyznaniowe. Ustawa z dnia 17 maja 1989 r. O gwarancjach wolności sumienia i wyynania. - Warszawa, 1989. - $396 \mathrm{~s}$.

38. Pešek J. Štátna moc a cirkvi na Slovensku 1948-1953 / J. Pešek, M. Barnovský. - Bratislava: VEDA, 1997. - 76 s.

39. Pietrzak M. Prawo wyznaniowe / M. Pietrzak. - Warszawa: Wydawnictwa Prawnicze PWN, 1999. - 432 s.

40. Rahner K. Atheismus / K. Rahner // Sacramentum mundi. Theologisches Lexikon für Praxis. - Bd1/Hrsg K. Rahner, A. Darlap. Freiburg, 1967. -S. 372-383.

41. Religiöser Wandel in den postcommunistischen Landern Ostund Mitteleuropas. - Wurzburg, 1998. - 176 s.

42. Šmid M. Priprava Základnej zmluvi medzi Slovenskou republikou a Svatou stolicou / M. Šmid // Ročenka Ústavu pre vzt'ahy štátu a cirkvi 1999. Bratislava, 2000. - $187 \mathrm{~s}$.

43. Staniszkis J. Post-Communism. The Emerging Enigma / J. Staniszkis. - Warszawa : Instytut Nauk Politycznych PAN, 1999. - 188 s. 
44. Szostkiewicz A. Religion after Communism / A. Szostkiewicz // Commonweal. - 09/24/99. - Vol. 126. - Issue 16. - P. 17-34.

45. Tretera J. R. Church and State in the Czech Republic / J. R. Tretera // European Journal for Church and State Research. - Peeters, Leuven. - 2001. Vol. 8. - P. 287-294.

46. Vaško V. Kronika katolickě cirkve c Českoslovnsku po druhě světove válce / V. Vaško. - Praha, 1990. - $231 \mathrm{~s}$.

47. Vaško V. Neumlcena kronika katolicke cirkve v Ceskoslovensku po druhe svetove valce / V. Vaško. - Praha, 1990. - 261 s.

48. Zenit International News Agency Daily Dispatch. - 2000. February 14, s. 2.

Information about the author:

Palinchak M. M.,

Doctor of Political Science, Professor, Dean of the Faculty of International Economic Relations, Uzhhorod National University 14, Universytetska str, Uzhhorod, 88000, Ukraine 